ppi $201502 Z U 4645$

Esta publicación científica en formato digital es continuidad de la revista impresa ISSN-Versión Impresa 0798-1406 / ISSN-Versión on line 2542-3185Depósito legal pp $197402 Z$ U34
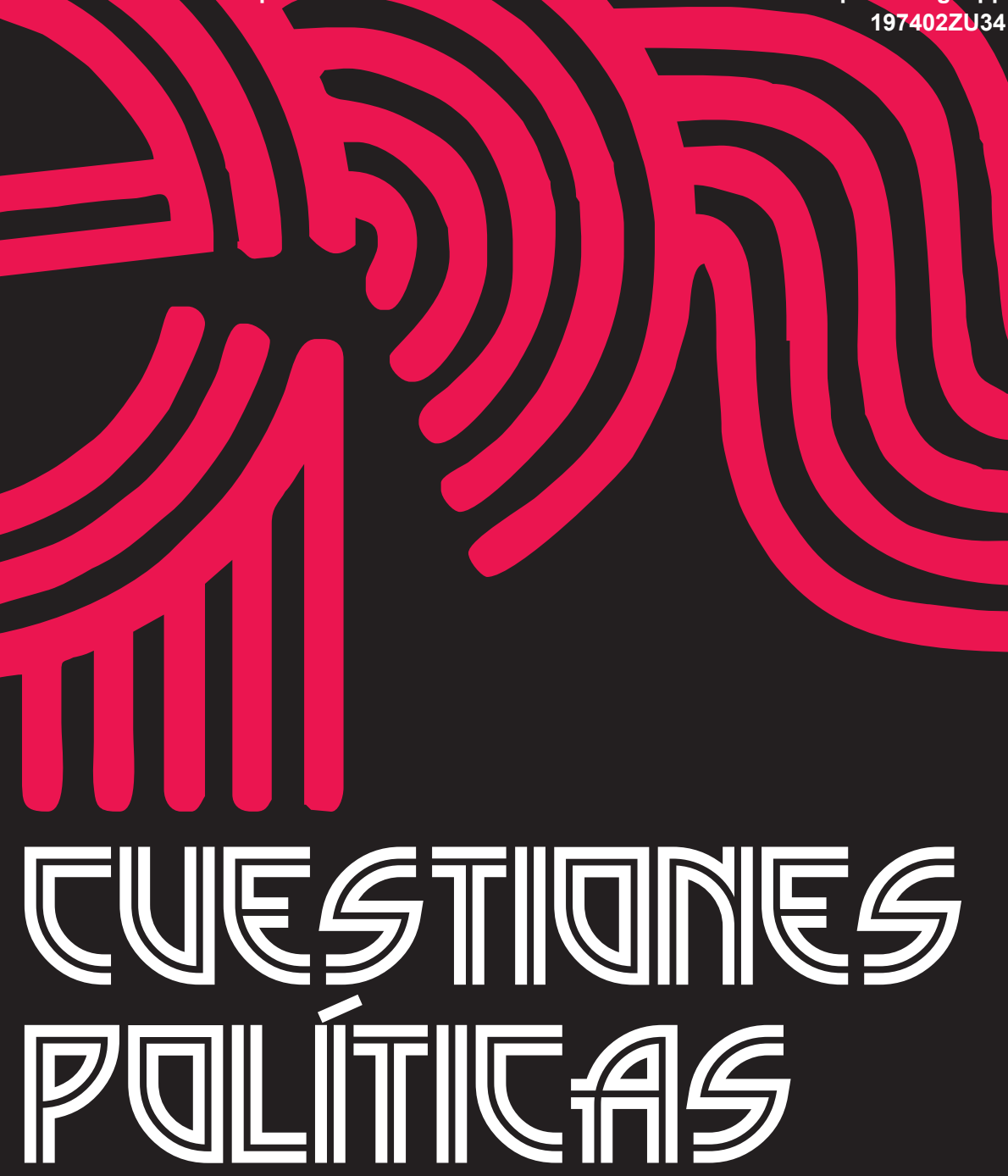

Instituto de Estudios Políticos y Derecho Público "Dr. Humberto J. La Roche" de la Facultad de Ciencias Jurídicas y Políticas de la Universidad del Zulia Maracaibo, Venezuela
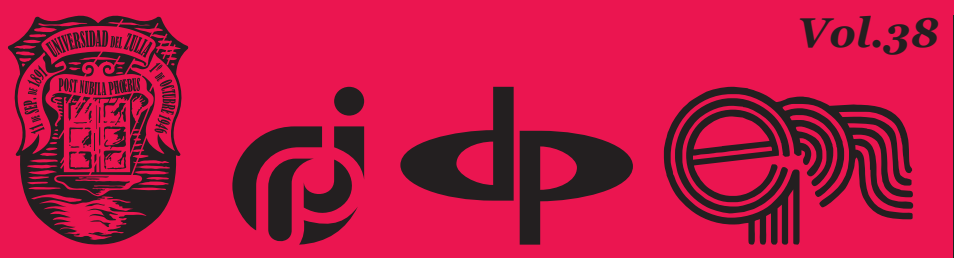

$N^{\circ}$ Especial 2da Parte 2020 


\title{
Socio-Political Aspects of Russian Muslim Pilgrimage to Mecca in the XIX-Th Century
}

\author{
DOI: https://doi.org/10.46398/cuestpol.382e.03
}

\section{Anvar Ajratovich Gafarov * \\ Mariam Arslanovna Galeeva **}

\section{Abstract}

Starting from the middle of the 16-th century, during the foreign policy expansion increase, the ethno-confessional diversity of the Russian state was steadily increasing. The imperial policy aimed at assimilating non-Russian peoples sharply raised the issue of their identity preservation. For domestic Muslims, an important factor in cultural and confessional identity provision was the preservation and development of their traditional ties with the Islamic world. Various political, economic, cultural, and other contacts maintained with the countries of the Muslim East have become the basis for the stability of the Muslim community in Russia under imperial pressure. In this system, a special role was originally played by the Hajj (Muslim pilgrimage to the holy places in the Hejaz), which the official administration had to reckon with. The aim of the proposed study is to identify socio-political aspects, socio-political conditions, and the specifics of the Hajj implementation in the 19th century. After the analysis of office documentation, travel notes of Muslim pilgrims, and expert assessments of orientalists, the authors concluded that, despite the increasing opposition from the authorities, the significance of the Hajj intensifies in the 19th century. Hajj became not only the factor of opposition to imperial acculturation, but also a channel for presentation the ideas of renewal.

Keywords: Hajj; Russian empire; Hijaz, Mecca; Muslim pilgrimage in the 19 th century.

\footnotetext{
* PhD in history, Associate Professor of the department Russian History, Institute of International Relations, Kazan Federal University. ORCID ID: http://orcid.org/oooo-0oo2-7708-5300. Email: anvargafarov@mail.ru

** PhD in history, Associate Professor at the Department of Russian History, Institute of International Relations, Kazan Federal University. ORCID ID: http://orcid.org/oooo-ooo2-6246-0577. Email: galeeva_mariyam@mail.ru
} 


\section{Aspectos sociopolíticos de la peregrinación musulmana rusa a La Meca en el siglo XIX}

\section{Resumen}

A partir de mediados del siglo XVI, la diversidad etno-confesional del estado ruso fue aumentando constantemente. La política imperial destinada a asimilar a los pueblos no rusos planteó agudamente la cuestión de la preservación de su identidad. Para los musulmanes domésticos, un factor importante en la provisión de su identidad cultural y confesional fue la preservación y el desarrollo de sus lazos tradicionales con el mundo islámico. En este sistema, originalmente el Hajj (peregrinaje musulmán a los lugares sagrados del Hejaz) desempeñaba un papel especial, que la administración oficial debía tener en cuenta. El objetivo del estudio fue identificar los aspectos sociopolíticos, las condiciones sociopolíticas y las particularidades de la implementación del Hajj en el siglo XIX. Para procesar las fuentes se hizo uso del método histórico. Después del análisis de la documentación recabada, las notas de viaje de los peregrinos musulmanes y las evaluaciones de expertos orientalistas, los autores concluyeron que, a pesar de la creciente oposición de las autoridades, la importancia del Hajj se intensifica en el siglo XIX. El Hajj se convirtió no solo en el factor de oposición a la aculturación imperial, sino también en un canal para presentar las ideas de renovación islámica.

Palabras clave: Hajj; Imperio Ruso; Hijaz, La Meca; peregrinación musulmana en el siglo XIX.

\section{Introduction}

The rapid expansion of the Russian state in the 16th - 19th centuries led to a significant increase of its population ethno-confessional diversity. The inclusion of numerous Muslim peoples in its composition caused the authority fears of "erosion" concerning the country ethnic-confessional foundations - the awareness of the so-called "Muslim issue" in Russia (Gafarov et al., 2017).

The specifics of the Russian state and religious system initially contributed to the manifestation of a rigid ethnic-confessional policy, which had a pronounced Christianizing character. The authorities took vigorous measures for the spiritual and cultural assimilation of the Muslim population. However, the effectiveness of rough persecution of disbelief, despite all its harshness, was insignificant (Solovyov, 1960). 
The search for ways to resolve the "Muslim issue" prompted the authorities to turn to the policy of acculturation (Gafarov, 2019) and to further strengthening of administrative and political restrictive measures. It is obvious that the search for ways to resolve the ethnic-confessional issue in line with the indicated paradigm remained an insoluble problem of Russian imperial policy until recent times.

The tough ethnic-confessional policy of the tsarist government, aimed at the Christianization and russification of the "foreign population", posed an urgent problem for the Muslim community concerning their identity preservation. In the conditions of imperial pressure, they had to seek actively the ways of survival, and adaptation to the conditions of existence (Gafarov, 2015).

\section{Methods}

The theoretical basis of the proposed study is represented by the ideas of the civilizational approach, the conceptual provisions of the Eurasian school and the theory of social modernization. In line with these views, an attempt was made to identify the socio-political aspects (socio-political conditions and specifics) of the Hajj implementation in the 19th century. The source corpus of the work consisted of clerical documentation of the administration of Kazan, Ufa, Orenburg, Perm provinces (allocated from the corresponding archival funds of the Republic of Tatarstan, the Republic of Belarus, SAOO, GAAO, GAPK, etc.), the travel notes of Muslim pilgrims (Sh. Mardzhani, Sh. Ishaev, S.G. Sultanov, etc.), the expert assessments of orientalists, etc., which reflected the official policy regarding the hajj, the opinions of Muslim pilgrims and the recommendations of orientalist experts.

\section{Results and Discussion}

An important factor of religious and cultural tie preservation was the Hajj, which, whenever possible, is prescribed for every Muslim (Peters, 1994). The Muslims of Inner Russia and Siberia, as a rule, left through Odessa and Sevastopol, from Central Asia and the Trans-Caspian region - through Batum, from Warsaw - by rail through Vienna to Istanbul. Afterwards, "Turkish steamers also carried a lot of indigent pilgrims in both directions for free" (Report of Staff Captain Davletshin about his trip to Hejaz, 1899). The routes also went through Afghanistan and India from the Turkestan region, and through Persia and Iraq from the Caucasus (Tashkent, 1899). 
Anvar Ajratovich Gafarov y Mariam Arslanovna Galeeva
50 Socio-Political Aspects of Russian Muslim Pilgrimage to Mecca in the XIX-Th Century

Among Russian pilgrims, the immigrants from Central Asia predominated.

Out of 1795 respondents at the consulate in Jeddah, 90\% were from the Turkestan region and the Bukhara Emirate, 2.8\% - from the North Caucasus, 2.5\% - Tatars, 4.7\% declared Russian citizenship (Tashkent, 1899). According to official figures, "the usual number of Mohammedan pilgrims from the Russian Empire ranges between 25,000 - 30,000 per year" (Latest news, 1898). It is impossible to calculate more precisely, "since the overwhelming majority of them go without any passports" (Tashkent, 1899). According to the consuls in Baghdad and Jeddah, "there are approximately 18-25 thousand Russian pilgrims at least" (Tashkent, 1899).

Despite the fact that worship cost "no less than 1,00o rubles in silver" (Schiele, 1879), some performed the Hajj more than once, stayed for a long time in Mecca and Medina. For example, the future teacher of the Galia madrasah S. Dzhiganshin studied and worked in the Hejaz for 18 years (National Archives of the Republic of Bashkortostan). Sh.M. Ishaev (an employee of the Russian consulate in Jeddah, 1896) discovered "many of our Central Asians" in Mecca who "do not think to return to their homeland at all" (Ishaev, 1896). A-A. Davletshin also notes that during his travel (1898) "there were 42 Russian Tatar students in Medina" (Report of Staff Captain Davletshin about his trip to Hejaz, 1899). The Kazanli madrasah was founded there in 1893 for Sunni Muslims from Russia.

The intensity and relevance of such contacts is evidenced by the fact that wealthy pilgrims from Russia bought and donated houses (dormitories) to wakuf "for free accommodation" and to facilitate the life of their fellow countrymen (Report of Staff Captain Davletshin about his trip to Hejaz, 1899). The Bukhara emir donated 100 thousand rubles in 1901 (the kushbei and the heir added another 100 thousand) "for the construction of the Hejaz railway to Mecca and Medina" (Galuzo, 1935: 41). ${ }^{3}$ Sufi brotherhoods also took part in money collection; in particular, numerous students of the Sheikh Z. Rasulev (Rasulev, 2011).

Hajj who returned home enjoyed high authority and respect from their compatriots (Schiele, 1879). From such travels, pilgrims brought not only religious relics, but also a significant number of books that replenished private collections and school libraries. Thus, by 1913, the fund of the library of the Embaevsky madrasah (near Tyumen) amounted to 2,200 books, including those purchased by the famous philanthropist N. Saydukov in Egypt, Syria, Jerusalem during his travels in 1866, and 1880-1881. Some were quite rare, but the prints from the Middle East were generally rather inexpensive. ${ }^{4}$

3 Hijaz railway was built in 1900-1909.

4 The Egyptians "republish European editions in Cairo... and sell them twenty, thirty times less than European editions” (Krymsky and Miller, 1903: 31). 
Returning from the Hajj, some pilgrims (Sh. Mardzhani, Sh. Ishaev, S.G. Sultanov, etc.) published the travel notes in which they tried to convey to the reader not only their impressions of the colorful journey, but also cultural traditions and the achievements the Muslim world. M. Simeti (1697/1698) was one of the first who described his journey to the holy places. During the pilgrimage, he visited Maverannahr, Khorasan, Iran, Iraq, Syria, and Hejaz. In 1860, the printing house of Kazan University published the travel notes of two pilgrims of the 18th century (Fahrutdinov, 2019). One of them, I. Bekmukhammedov, is from Kargaly, Orenburg province. He went to Mecca in 1751 through Bukhara, Afghanistan and India. The other is M. Amin from the village of Yana Kishit, Kazan province. He completed the Hajj in 1783 through the Caucasus, Istanbul and Egypt. The book describes passing areas, cities, villages and peoples (Solovyev, 1896).

Pilgrimages led to a wide variety of contacts, sometimes beyond the scope of religious and spiritual searches. ${ }^{5}$ For example, during the Hajj (1893), Mufti M. Sultanov was received by the Sultan and awarded the Order of Osmania, 2nd degree. Sh. Mardzhani, S-G. Sultanov cautiously notes the contacts with politicians, and prominent state dignitaries (Essays by Mardjani on the Eastern peoples, 2003; Sultanov Haji Salim Girey, 1901). Speaking about the Russian Muslims permanently living in Medina, S.-G. Sultanov writes that some of them have achieved a very high position. For example, the governor of Medina, Osman Pasha - a former Russian, Circassian from the Caucasus; his son-in-law is the son of the famous Shamil, Gazi-Muhammad and others (Sultanov Haji Salim Girey, 1901).

Probably, it is far from accidental that the Russian government, starting with the seizure of the Volga khanates, tried to limit the pilgrimage of subordinate Muslims at least temporarily. Along with political reasons, there were quite justified fears of bringing epidemics and diseases raging in the East into the country. In response to a warning about a pestilence that opened in Istanbul (1812), the Astrakhan governor ordered the adoption of the most "stringent ("quarantine") measures so that this evil could not penetrate, from which God forbid!" (State Archives of the Russian Federation (SA RF)). However, political motives still prevailed. In 1822, the petition by General Ermolov A.P. was answered as follows: "The Emperor deigned to prohibit the inhabitants of our Muslim regions to go to Mecca to worship for a while" (Imperial Russia and the Muslim World, 2006: 480).

In 1843, the Minister of Defense Chernyshev A.I. recommended to the Governor-General of Orenburg the following: "to reject pilgrims from traveling to Mecca and Medina under various plausible pretexts" in view of the fact that "many of them upon their return... produce an adverse effect for us on their fellow believers" (Imperial Russia and the Muslim World, 2006: 
480). With the beginning of the occupation of Turkestan, a temporary ban on the issuance of passports to Muslims was reintroduced by the order of Count P.A. Valuev (1865).

The documents show that, despite the ban, permits for the Hajj were still issued (but in an exceptional manner, with the knowledge of the Minister of Internal Affairs) (State Archives of the Perm Region). In 1865 and 1869 the Ministry of Internal Affairs adopted secret circulars strictly regulating the departure of Muslims abroad. A person leaving had to buy 2 stamps (6o kopecks each) to pay for a certificate issue to the port city and submit 2 semi-imperials (or 10 rubles) to ensure the return home. He was also obliged to present a certificate of the volost government on the absence of arrears and the obligation of relatives to perform duties for him (State Archives of the Perm Region).

In 1866, due to unrest in the Tatar area, starting in May, they stopped issuing permission to leave for Muslim priests (National Archives of the Republic of Tatarstan; Sultanov Haji Salim Girey, 1901). At the same time, the permits continued to be issued to peasants, merchants, bourgeois and others. Some imams, such as M. Abdullin from the village Kutlu-Bukash (Laishevsky uyezd), having received a refusal, filed a second application a few months later, but was refused agin (National Archives of the Republic of Tatarstan). This practice continued in the future. For example, on the petition of the imam from Tatar Saraly village (Laishevsky uyezd) Kh. Mukhametsalimov (1879) the police chief wrote that in 1878 this imam went with other Tatars to St. Petersburg to file a complaint about the brutal actions of the administration during unrest suppression, that he was traveling around Spassky and Chistopolsky districts "probably with the aim of maintaining unrest and disobedience to local authorities among the Tatars."

The Governor N.Ya. Skaryatin, against whom the complaint was filed, spoke out more definitely: Mukhametsalimov "was one of the people who campaigned among the Tatar population of the Kazan province in the past winter by spreading various false rumors about the alleged baptism of the Mohammedan Tatars." The Director of the Department of Spiritual Affairs imposed a resolution accordingly: "In view of the information reported about this person, I find it necessary to reject his petition" (National Archives of the Republic of Tatarstan).

In 1881, the borders for pilgrims were opened and the faithful reached for the holy places again. The official press, trying to restrain the flow, described the "horrors" of travel: there was pandemonium in the Hejaz, 350 thousand pilgrims, the prices of camels from Mecca to Medina increased more than twice, there were robbers on the roads, etc. Eight years later, in 1889, and 
then in 1890 (under the pretext of a cholera epidemic in Arabia ${ }^{6}$ ), a ban of traveling abroad was imposed on Muslims once again. In June 1891, the restrictions were temporarily lifted, but a month later the ban on traveling to Arabia was reinstated: "to prevent the introduction of infection into the Empire ..." (State Archives of the Perm Region), In 1893, 50 thousand hajis died from cholera, including 700 Russians. However, the next year the epidemic began to decline, mortality decreased by 8 times (Tashkent, 1899). Thus, the ban (with interruptions) lasted until 1900.

\section{Conclusions}

The routes of Russian pilgrims, as a rule, ran through Istanbul, Cairo, Damascus, Beirut, Baghdad and other centers of Islamic culture, social and political life. Long and difficult travels to holy places contributed not only to the acquaintance with cultural values, but also to closer communication of Muslims from different countries, exchange of views and awareness of the common problems of the Muslim world development. Assessing the significance of the Hajj, S-G. Sultanov, first of all, emphasized that "the Hajj was important, since it introduced Muslims to each other, broadening their mental horizons, presenting the idea of religious unity in a visual way" (Sultanov Haji Salim Girey, 1901: 20).

However, according to a number of experts, along with the Hajjis, radical ideas (Wahhabism, Mahdism, Sinusism, etc.) sometimes penetrated into Russia, "the unity of Muslims not only on a religious basis, but also on a political one" (Eliseev, 1886: 27). As N.P. Ostroumov notes: "the Muslim pilgrims - the Russian citizens who went to Mecca and Medina - strove to see and bow to Mahdi, who was already operating in Sudan," (Ostroumov, 1889: 99). "There is no doubt that the pilgrims bring the news of fermentation in Turkey," reports the Orenburg police chief, "spread them among the population" (State Archives of the Orenburg Region). The Astrakhan police believed that pilgrims brought Young Turkish literature, newspapers and magazines (State Archives of the Astrakhan Region). The Kazan governor also believed that the pro-Turkish sentiments were spread by the pilgrims returning from Mecca and Medina (National Archives of the Republic of Tatarstan). "Thus, Kaaba (according to the official bodies) serves as the center for religious propaganda, political upheavals, and unrest in the Muhammadan world during the Hajj” (Timofeeva et al, 2019),

6 During the Hajj, the first Russian consul in Jeddah Ibragimov Sh.M. died of cholera (1892). He was buried in the cemetery of Jeddah. The Mufti Sultanov M. fell ill with a fever. In 1897, due to the outbreak of an epidemic in India (which could spread to the Hejaz), he turned to the akhuns and mullahs to refrain «from traveling to the Hajj» (Collection of circulars and other guiding orders for the district of the Orenburg Mohammedan Spiritual Assembly, 1836). 
the dissemination of ideas hostile to "the good objectives of order and our state life" (Tashkent, 1899).

Miropiev M.A., exposing the "political harm" of the Hajj, hoped for the publication of "a permanent ban on the travel of Muhammadan to Mecca" (Miropiev, 1881), which was practically implemented in Soviet times.

After a long period of severe religious restrictions in the USSR, with the liberalization of state-confessional relations in Russia, the problem of pilgrimage has regained its relevance, invoking the historical experience and traditions of the past (Timofeeva et al., 2019).

In order to resolve the doubts of the Russian government about the Hajj, in 1898, under the guise of a pilgrim, the Captain A.A. Davletshin was sent to the Hejaz. At the end of his trip, he presented a Report in which he gave a fairly detailed description of the natural conditions, population, socio-economic state of the region - the conditions for passing the Hajj. To Davletshin's credit, he tried to "calm down" anxious minds. Describing the difficulties of travel (its high cost, discomfort, terrible climatic and hygienic conditions, abuses of local officials, etc.), without denying "that the Hajj serves a certain uplift of religious feelings," he claims that "almost all of our pilgrims return to their homeland with significantly changed views, more clear-cut and with a more conscious attitude to the political state of affairs, the coloration in which they previously imagined Muslim Turkey and its head, the Caliph, completely disappears." Hajj "does not lead to any rapprochement (of Muslims - A.G., M.G.) and this idea itself does not exist."

Moreover, our pilgrims, "perhaps unconsciously, carry the glory of Russia before the Hejaz", "with their enthusiastic stories" about the power of Russia, about the justice of the existing order, "about the wealth of our country, about the abundance and cheapness of food there", etc., contribute to the growth of its authority in the Muslim East (Report of Staff Captain Davletshin about his trip to Hejaz, 1899). As for epidemics, Davletshin also tried to "calm down" the government: diseases spread mainly among poor pilgrims, "it occurs between them as a very rare exceptional phenomenon" (Report of Staff Captain Davletshin about his trip to Hejaz, 1899).

In general, "it is difficult to indicate any valid measures so that, if necessary, it would be possible to stop the departure of our Muslims to the Hejaz" (Report of Staff Captain Davletshin about his trip to Hejaz, 1899). Soon, the issuance of pilgrim passports to Russian Muslims resumed again. This was announced to Muslims by the Orenburg Mohammedan Spiritual Assembly: "about the subsequent permission of the pilgrimage to the Hejaz and Arabia" (Collection of circulars and other guiding orders for the district of the Orenburg Mohammedan Spiritual Assembly, 1836: 228).7 Since

7 In spite of the positive decision, the issue of "allowing the Mohammedans leave for Mecca" was later raised again in 1904 (State Archives of the Orenburg Region). 
1903, the number of pilgrims from Russia began to grow steadily (History of hajj in Russia from $18^{\text {th }}$ to $21^{\text {st }}$ century, 2011).

\section{Acknowledgements}

The work is performed according to the Russian Government Program of Competitive Growth of Kazan Federal University.

\section{Bibliographic References}

COLLECTION OF CIRCULARS AND OTHER GUIDING ORDERS FOR THE DISTRICT OF THE ORENBURG MOHAMMEDAN SPIRITUAL ASSEMBLY. 1836. (1836-1903). Ufa, Russia.

ELISEEV, Alexey V. 1886. Senusi Religious Union and Its Significance for Russia. St. Petersburg Gazette. St. Petersburg, Russia.

ESSAYS BY MARDJANI ON THE EASTERN PEOPLES. 2003. Publishing House. Kazan, Tatar.

FAHRUTDINOV, Rezida; FAHRUTDINOV, Billy; KUZNECOVA, Edvard. 2019. "Tourist directions and routes of the sacred and pilgrims in the Ulyanovsk region" In: Humanities \& Social Sciences Reviews. Vol. 10, No. 2, pp. 158-159.

GAFAROV, Aleksandr. 2019. "Educational policy of the Russian empire in the Turkistan region (The second half of the XIXTH-the beginning of the XXTH century)" In: International Journal of Innovative Technology and Exploring Engineering. Vol. 9, No. 1, pp. 5180-5183.

GAFAROV, Anvar. 2015. "Russian Muslim Lifestyle Renovation Problems in the Modernistic Literature of the Late 19th and Early 20th Century" In: Journal of Sustainable Development. Vol. 8, No. 7, pp. 178-184.

GAFAROV, Anvar; NABIEV, Rashit; FAZLIEV, Andre; NAFIKOV, Iinda. 2017. "«Muslim matter» in the mirror of public discussion (XIX-beginning of XX century)” In: Journal of Fundamental and Applied Sciences. Vol. 9, No. 7 S, pp. 1257-1265.

GALUZO, Petr Grigorevič. 1935. Turkestan-colony. State publishing house of the UzSSR. Tashkent, Uzbekistan. 
Anvar Ajratovich Gafarov y Mariam Arslanovna Galeeva
56 Socio-Political Aspects of Russian Muslim Pilgrimage to Mecca in the XIX-Th Century

HISTORY OF HAJJ IN RUSSIA FROM $18^{\mathrm{TH}} \mathrm{TO} 21^{\mathrm{ST}}$ CENTURY. 2011. Islam.ru, July 12. Available online. : In: http://islam.ru/en/content/story/historyhajj-russia-18th-21st-century. Consultation date: 02/05/2020.

IMPERIAL RUSSIA AND THE MUSLIM WORLD (LATE 18TH - 20TH CENTURIES). 2006. Collection of Materials. M. Natalis, - 480 p.

ISHAEV, Salman. 1896. Mekka, sviashchennyi gorod musul'man (Rasskaz palomnika). Mecca, the Sacred City of the Muslims (Story of a Pilgrim), The Central Asian Herald. Sredne-Aziatskii vestnik. Ezhemesiachnyi nauchno-literaturnyi zhurnal. Noiabr.

KRYMSKY, Agafangel Efimovich; MILLER, Brian. 1903. All-Muslim University at the Azhar Mosque in Cairo. Cairo, Egypt.

LATEST NEWS. 1898. Kazan Telegraph. 1647. Kazan, Russia.

MIROPIEV, Michail. 1881. Religious and political significance of the Hajj or the sacred travels of Muhammadan to Mecca for a religious celebration. Orthodox interlocutor, Part II, 77-120, 305-330, 435-438.

NATIONAL ARCHIVES OF THE REPUBLIC OF BASHKORTOSTAN. - F. R-4767. - Inv. 1.- F. 1.- Sh. 14.

NATIONAL ARCHIVES OF THE REPUBLIC OF TATARSTAN. - F. 1. - Inv. 3.C. 235.- Sh. 17, 51, 60, 61, 84, 99; C. 4611. Sh. 232, 236, 238.

NATIONAL ARCHIVES OF THE REPUBLIC OF TATARSTAN. - F. 199. - Inv. 1. - C. 906. - Sh. 112.

OSTROUMOV, Natalia. 1889. Sudanese Mahdi and the uprising of Sudanese Muslims that arose in 1881. Extracted from the magazine «Wanderer» (1890).

PETERS, Francis E. 1994. The Hajj: The Muslim Pilgrimage to Mecca and the Holy Places. Princeton University Press. New Jersey, United States.

RASULEV, Bakhtiyor. 2011. Zaynullah ishan. Makalat Zainiya: Bocetos de Zainullah Ishana. Zaynullah Ishan Rasulev. AYa GROUP. Kiev, Ukraine. (In Ukrainian).

REPORT OF STAFF CAPTAIN DAVLETSHIN ABOUT HIS TRIP TO HEJAZ. 1899. Secret. $-\mathrm{SPb},-145 \mathrm{p}$.

SCHIELE, François. 1879. Kazan Tatars. Ethnographic sketch. Nature and people. Kazan, Russia. 
SOLOVYEV, Andre. 1896. Catalog of books printed in the printing house of the Imperial Kazan University from 1800 to 1896 . Kazan, Russia.

SOLOVYOV, Sergey. 1960. History of Russia since ancient times. In fifteen books. M.: Publishing house of socio-economic literature. Moscow, Russia.

SULTANOV HAJI SALIM GIREY. 1901. The sacred area of Muslims in Arabia (From the memoirs of a pilgrim). Geography. I-II, 85-144.

TASHKENT, Vildamos. 1899. Pilgrimage (Hajj) to Mecca and Medina. Materials on Islam. Moscow, Russia.

TIMOFEEVA, Larisa; AKHMETOVA, Alma; GALIMZYANOVA, Liliya Rifkhatovna; FOMINYKH, Andre; MUNINA, Yusufu. V. 2019. "The history pages of orthodox pilgrimage: from worship to pilgrim tourism" In: Utopía y praxis latinoamericana: revista internacional de filosofía iberoamericana y teoría social. Vol. 5, pp. 32-37. 
Vol.38 NEspecial

Esta revista fue editada en formato digital y publicada en diciembre de 2020, por el Fondo Editorial Serbiluz, Universidad del Zulia. Maracaibo-Venezuela 